\title{
Kernos
}

Revue internationale et pluridisciplinaire de religion grecque antique

$21 \mid 2008$

Varia

\section{The Sins of the Fathers: C.A. Lobeck and K.O. Müller}

\section{Renaud Gagné}

\section{Journals}

\section{Electronic version}

URL: https://journals.openedition.org/kernos/1606

DOI: 10.4000/kernos.1606

ISSN: 2034-7871

\section{Publisher}

Centre international d'étude de la religion grecque antique

\section{Printed version}

Date of publication: 1 January 2008

Number of pages: 109-124

ISSN: 0776-3824

Electronic reference

Renaud Gagné, "The Sins of the Fathers: C.A. Lobeck and K.O. Müller", Kernos [Online], 21 | 2008, Online since 01 October 2011, connection on 24 August 2022. URL: http://journals.openedition.org/kernos/ 1606 ; DOI: https://doi.org/10.4000/kernos.1606 
Kernos 21 (2008), p. 109-124.

\title{
The Sins of the Fathers: C.A. Lobeck and K.O. Müller
}

\begin{abstract}
The notion of "inherited guilt," or ancestral fault, has played a prominent role in scholarship on ancient Greek religion and literature. Although it corresponds to no clearly circumscribed ancient concept, it has acquired something of a self-evident value in philological research. Shaped by centuries of ideological involvement with the Greek material, and by the apparently equivalent Judeo-Christian notions of corporate responsibility and original sin, the term "inherited guilt" imposes a heavy baggage of assumptions and resonances on the material it is meant to describe and translate. Rather than abandoning "inherited guilt" altogether, or simply deconstructing it away, as some scholars have suggested in recent years, a new perspective grounded in a detailed understanding of its tradition is needed to make sense of the abundant and complex material at hand. A thorough engagement with the religiously charged tradition of scholarship is one of the keys to a fruitful redefinition of Greek ancestral fault. The present paper proposes to revisit the seminal discussions of the two contemporary scholars who pioneered the modern professional study of Greek religion: C.A. Lobeck and K.O. Müller.
\end{abstract}

Résumé : Les crimes des pères: C.A. Lobeck et K.O. Müller. La notion de "péché héréditaire ", ou faute ancestrale, a joué un rôle important dans la recherche sur la religion et la littérature grecques. Bien qu'elle ne corresponde à aucun concept ancien clairement déterminé, elle a acquis une signification précise dans les études philologiques. Forgée par des siècles de lecture idéologiquement chargée, et par l'apparente adéquation du matériel grec avec les notions judéo-chrétiennes de responsabilité collective et de péché originel, la notion de "péché héréditaire» impose un lourd bagage de présupposés et de résonances au matériel qu'elle entend décrire et traduire. Cependant, plutôt que de la rejeter complètement ou de la déconstruire, comme on l'a proposé ces dernières années, une nouvelle perspective est nécessaire pour donner sens au vaste et complexe matériel en question. Cette perspective devra s'appuyer sur une compréhension détaillée de la longue tradition de réception en cause. C'est là une des clés au succès d'une redéfinition fructueuse de la faute ancestrale grecque. Cet article propose de revisiter les discussions fondatrices de deux savants contemporains, pionniers des études professionnelles et modernes sur la religion grecque ancienne : C.A. Lobeck et K.O. Müller.

The concept of "inherited guilt" has played a key role in the modern scholarship of ancient Greece. ${ }^{1}$ Although it translates no ancient equivalent, this

\footnotetext{
${ }^{1}$ Contributions to research on the topic since the seminal work of GLOTZ in (1904) include VALlois (1914); KAKRIDIS (1929), p. 141-168; DODDS (1951), ch. 2; MOULINIER (1951), p. 228 241; LLOYD-JONES (1962), (1971), and (2002); GANTZ (1982); PARKER (1983), p. 199-206; WeST (2002); SEWELL-RUTTER (2007).
} 
term, together with similar coinages such as "Erbschuld" and "péché héréditaire," has been used to interpret material from most genres of Greek literature and all periods of Greek history since the early modern period. ${ }^{2}$ Not only does the term "inherited guilt" correspond to no ancient emic category, however, but it imposes, more significantly, a deep range of Christian associations upon the Greek material. This has long been recognized by classicists. ${ }^{3}$ The mention of "inherited guilt" activates an entire web of Christian concepts and references, implicit theological programs and Biblical correspondents. The long and eventful interpretatio christiana of the Greek sources has charged the ideas and the images linked to Greek conceptions of punishment through generations with the doctrines of another religious tradition. The English term "inherited guilt," for instance, is itself a direct translation of the earlier German terms Erbschuld or Erbsïnde. These German words have been used in philological scholarship from the early $19^{\text {th }}$ century to the present day to describe the Greek material of punishment through generations. They are, of course, highly marked theological terms of reference for the Christian notions of original sin and corporate responsibility. ${ }^{4}$ Both ultimately derive from terms such as the Patristic Latin baereditarium peccatum, a composite formation used by later Church Fathers in reference to the then emergent notion of Christian original sin. ${ }^{5}$ The usage of such terms of appropriation to describe this concept of pagan Greek culture is a direct application of Christian filters on the ancient material - translating one tradition through another. "Inherited guilt" and its equivalent terms are heavily charged concepts. They probably carry too much ideological baggage to retain any utility at this point.

Whatever the stakes and baggage of this ideological tradition, however, and the analytical problems of preceding definitions, we cannot limit ourselves to analyzing away "inherited guilt" by simple deconstruction. The Greek expressions of divine punishment through generations are tied to a distinct

${ }^{2}$ I will only use the term "inherited guilt" in the following discussion in reference to earlier scholarship. The more theologically neutral "ancestral fault" is a closer rendering of the major terms of reference actually used in antiquity in reference to delayed generational punishment. These terms include $\pi \alpha \lambda \alpha i \gamma \varepsilon v \dot{\eta} \varsigma$ $\pi \alpha \varrho \beta \alpha \sigma i \alpha$ (Aesch., Suppl., 265), $\pi \alpha \lambda \alpha$ li $\alpha \dot{\alpha} \mu \alpha \varrho \tau i \alpha l$ (Aesch., Ag.,

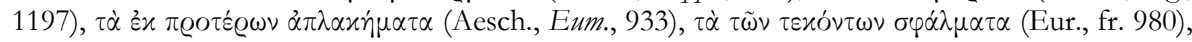

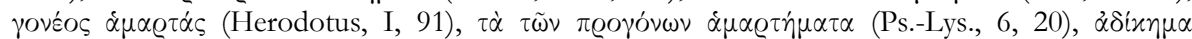

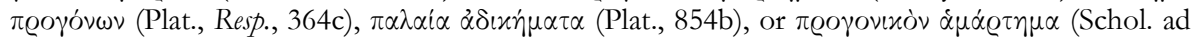
Eur., Hipp., 833). "Ancestral fault" will be used instead of "inherited guilt" in the following discussion as a general descriptive term for the idea of delayed generational punishment.

${ }^{3}$ Wilamowitz, for instance, was particularly careful already in distinguishing what he saw as the hereditary transmission of sin in Greek religion from the Christian Erbsïnde: WiLAMOWITZ (1932), p. 122-123. It is ironic that, in the index to the first volume of his Kleine Schriften by Franz Hiller von Gaertringen and Paul Maas, his 1880 discussion of ancestral fault in the Hippolytus (1971, p. 19) is referenced by the term Erbsïnde.

${ }^{4}$ See e.g. SCHUBERT (2002).

${ }^{5}$ E.g. Ambr., De Myst., I, 32; cf. Rondet (1966); Dubarle (1999); Minois (2002), p. 43-80. 
tradition of vocabulary and imagery. The abundant material which expresses this idea in ancient Greek literature belongs to a common horizon of reference which has never been analyzed in detail. One of the keys to making sense of this rich material is reception. The long modern reception of the concept of ancestral fault has accrued layer upon layer of meanings over the Greek material, and any new engagement with it has to take the enduring force of this tradition seriously. An archaeology of "inherited guilt" as a modern concept of scholarship is necessary before an archaeology of ancestral fault as an ancient concept of culture is possible. As a contribution to this effort and as part of preliminary work towards a monography on Greek ancestral fault, the following pages will review and contextualize two of the seminal discussions of modern scholarship on the question, the work of two scholars generally seen as the founding fathers of the modern, "scientific" study of Greek religion: Christian August Lobeck (1781-1860), and Karl Otfried Müller (1797-1840).6

\section{C.A. Lobeck: Aglaophamus (1829)}

The Aglaophamus, sive de theologiae mysticae Graecorum causis, the monument of Prussian erudition published by Christian August Lobeck in 1829, marks the beginning of modern philological research on Greek religion. The Aglaophamus was written as a reaction against Romantic and Symbolic domestications of ancient religion: the neo-pagan followers of Schiller and Goethe, the many enthusiasts of $18^{\text {th }}$ century pantheism, and especially Friedrich Creuzer's 18101812 (2nd ed. 1819-1828) massive Symbolik und Mythologie der alten Völker, besonders der Griechen, which had revived the idea of natural religion and the material of $17^{\text {th }}$ century mythological comparatism, particularly the ideas of Vossius. ${ }^{7}$ Creuzer tried to show that all the faiths of the world were united in common symbolic patterns stemming from human nature, and from an antediluvian revelation transmitted to the world by prehistoric missionaries from India and Egypt. ${ }^{8}$ In the same way that the odd enterprise of Creuzer descends in direct line from the theorists of natural religion and the humanist comparatists of the circle of Grotius and Vossius, Lobeck clearly belongs to the old tradition of Protestant apologists writing on "Papism" through paganism.9 The Aglaophamus, usually described as a pure product of enlightened rationality, is also very much a traditional tool in the defense of faith. Lobeck wanted to neutralize the religious value of classical cults, especially the supposedly mystical aspects of the Mysteries of Eleusis, of Samothrace, and of the religious literature ascribed to the singer Orpheus, the Orphica. Using positive reason as a

\footnotetext{
${ }^{6}$ BURKERT (1980), p. 162-163.

7 Momigliano (1946).

8 See Momigliano (1946); (1983); MÜnCH (1976).

${ }^{9}$ See Gagné (2008).
} 
tool of demystification, he proceeded to detach ancient religion from its aura of uncanny fascination, and expose its so-called mysteries as risible superstitions and obscene savagery. The speculations of the Neoplatonists, and of Proclus in particular, were shown to be late and inconsequential fabulations, and those "mystical" cults themselves were shown to be later and derivative products of Priestertrug, or cynical religious manipulators like Pythagoras or Onomacritus.

In the Aglaophamus, a tour de force of positive rationalism, Lobeck systematically collects and discusses the entire range of material concerning the "mystical" cults of the Greeks. The almost fourteen hundred pages of cautious classification of documents, careful philological criticism, and detailed source analysis, aim to take away all possible obscurity. There is no mystery: just a collection of carefully inventoried banalities, and many shocking aberrations. The cults which come from the East, brought in by the followers of Cybele and others, are in Lobeck not hallowed examples of some superior wisdom carried by the heroic Brahman missionaries of Creuzer, but the barbarous superstitions of insane charlatans. ${ }^{10}$ They are the artificial aberrations which have corrupted the pure and simple national faith of the Hellenes exemplified in Homer. Rituals are described with disdain and a relish for the odd detail; portraits of exotic ritual performance and the strange manipulations of strange objects are designed to bring out their status as mere collections of improvisations. The similarities and the continuity between the superstition of these primitive rituals and beliefs, and the sacraments of the Catholic Church, are also repeatedly brought back to the attention of the reader. Creuzer was accused of being a crypto-Catholic by Lobeck. The very last page of the Orphica even compares the religious impostors of antiquity to the obfuscations of those who Lobeck saw as the religious impostors of the modern age, the Jesuits. ${ }^{11}$ This is the context in which the Aglaophamus discusses the concept of ancestral fault.

In the Aglaophamus, the ancient Greek ideas of ancestral fault are discussed in the context of the Orphic Zagreus legend. ${ }^{12}$ They are shown to be a popular constitutive element of superstition that was used in the development of purification beliefs, and in the bricolage of the late and inauthentic "Orphic myth of original sin." In chapter 8 of the Orphica, Lobeck aims to show that the savage tale of the death of Zagreus is a late, post-Homeric invention. ${ }^{13}$ This is the myth that had been thought by most people, then as now, to be the kernel of the "Orphic faith." 14 According to Lobeck, the myth was first assembled by Onomacritus. It is an obscaena fabula stitched from a number of different sources

${ }^{10}$ LOBECK (1829), p. 632-633.

${ }^{11}$ LOBECK (1829), p. 964.

12 LOBECK (1829), p. 634-639, which stands within Chapter VIII of the De Zagrei morte (р. 615-699).

${ }^{13}$ LOBECK (1829), p. 601-699.

14 See now E.G. EDMONDS (1999); BERNABÉ (2002); (2003). 
and later adopted by the Greeks' fickle and inconstant religious spirit. ${ }^{15}$ Such tales and the rites which accompany them are answers to deep pathologies of the psyche, especially the hysterical impulses of women; Lobeck, for instance, cites with approval in this context Doctor Johann Heinrich Feustking's bizarre and influential Gynaeceum baeretico-fanaticum (1704). ${ }^{16}$ According to Lobeck, the effeminate Phrygian rites at the core of the Orphic faith were celebrated by the

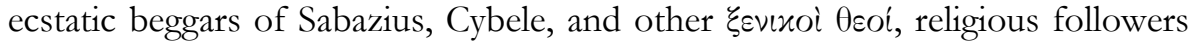
who performed the most bizarre and horrible acts imaginable for their mystici circuli. Even "more worthy of censure" are the antistites of their cults, the priests who, like the magicians of the day, were trained in the "occult arts." 17 They promised riches to some, friendship of gods and men to others, healing of the body also, made philters and poisons, etc. They also sold remission of sins (veniam peccatorum). Lobeck, echoing earlier Protestant scholarship on Greek religion such as the De Lustrationibus of Jan Lomeier (1681), gives many examples of the types of stain and pollution with which the superstitious thought they were soiled, and of the Catholic-like lustrationes which the charlatans offered them in exchange. This is the context of the passage where he discusses ancestral fault.. ${ }^{18}$

Before the priests and charlatans imposed their beliefs about purification on Greek culture, the superstitiosi, says Lobeck, feared the angry souls of the dead and their terrifying attacks much more than the gods. Crimes within the family were punished by the ancestors of the group on their descent. This wrath from the family gods held the group together in common sanction. Ancestors functioned as the guardians of morality. The luculentissimus interpres of this belief, Aeschylus, gives voice in the Oresteia to the life of fear in which people lived, gripped by the terror of an ancient guilt they couldn't know and a punishment which could strike at any time. The word for sin, $\alpha \mu \alpha \varrho \tau \eta \dot{\mu} \mu$, is used to described the domestic faults "by which the rights of the family are violated," according to Lobeck. This $\dot{\alpha} \mu \propto \varrho \tau \eta \dot{\eta} \mu \alpha$ is the result of an offense against the family and its protector gods, figures like the $\theta$ soi $\pi \alpha \tau \varrho \tilde{\omega} O \iota$, Zeus Xenios, Zeus Homognios, and the Erinyes. One of the punishments they can inflict is infertility and loss of children, and this is one of the reasons why the Athenians

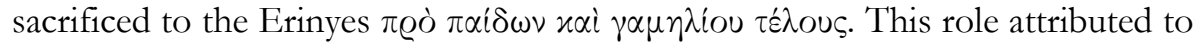
family gods as figures of fertility derives from the "common belief of all Antiquity" that "piety and obeisance for parents is the greatest foundation of all domestic prosperity." 19 The family gods and the dead ancestors can contribute to the wealth of the clan, the prosperity of its fields, the birth of children; they can also, when their honor has been offended, take away all hope of fecundity.

\footnotetext{
15 LOBECK (1829), p. 610-615.

16 LOBECK (1829), p. 629-630; see GösSMANN (1998).

${ }_{17}^{17}$ LOBECK (1829), p. 632.

${ }^{18}$ LOBECK (1829), p. 634-639.

${ }^{19}$ LOBECK (1829), p. 636.
} 
Lobeck finds traces of this primitive conception of the familiarum iura in Homer, and even has a positive word for it as the expression of a magnifica professio.

With the rise of belief in pollution and purification, this punitive power of ancestors was perceived behind pathological mental imbalance and madness. Plato's Phaedrus offers the most famous example of the type of madness which was thought to result from the fear of ancestral fault, the $\mu \alpha v i \alpha \tau \varepsilon \lambda \varepsilon \sigma \tau \iota x \eta^{\prime}$ of 244d:

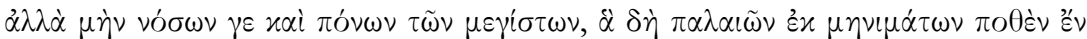

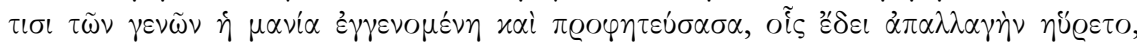

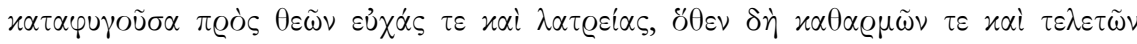

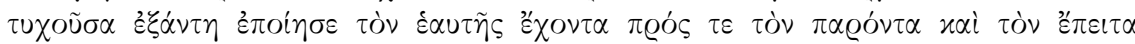

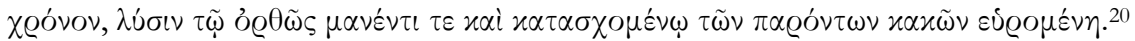

Moreover, when diseases and the great troubles have been visited upon certain families through some ancient guilt, madness has entered in and by oracular power has found a way of release for those in need, taking refuge in prayers and the service of the gods, and so, by purifications and sacred rites, he who has this madness is made safe for the present and the after time, and for him who is rightly possessed of madness a release from present ills is found. ${ }^{21}$

The $\gamma^{\prime} v \eta$ of év $\tau \iota \sigma \iota \tau \tilde{\omega} \nu \gamma \varepsilon v \tilde{\omega} \nu$, argues Lobeck, does not refer to the families of the purifying priests, as others had thought before, but to those "cursed" families affected by the pollution of an ancestral evil. ${ }^{22}$ The $\pi \alpha \lambda \alpha i \dot{\alpha} \mu \eta \nu i \mu \alpha \tau \alpha$ now had their origin in the vengeful wrath of ancestors against their descendants. They were seen as the expression of the offended power of the family gods for crimes committed against them. The power of the hereditary evil (vis haereditari mali) could hide in a family for generations and resurface at any time, and the belief in its prevalence was so strong that any affection of the soul or the body was thought to have its origin in this wrath of the dead. Quoting a passage from Plutarch's Life of Solon, Lobeck says that those who thronged the cemeteries at night were thought to be afflicted by womanly and effeminate pains on account of sins committed within the $\gamma^{\prime} \dot{v} \eta$; he continues by asserting that the torments and disorders of the melancholics and the lycanthropes who were used to wander around tombs and graves were also believed to result from the obscure power of the ghosts over their descendants. ${ }^{23}$ Even the madness of love occasioned by a young girl's passion could be interpreted as such a form of punishment from the ancestors. According to Lobeck, the telestic madness described by Plato in Phaedrus 244d was thought to be another symptom of this "silent power of ancestral fault" (vis tacita avitae noxae), and it

\footnotetext{
${ }^{20}$ LOBECK (1829), p. 636.

${ }_{21}$ Plato, Phaedr., 244de (trans. Fowler).

22 LOBECK (1829), p. 636-637; see LiNFORTH (1946b).

${ }^{23}$ LOBECK (1829), p. 638-639.
} 
was believed that the mad words of those who were afflicted by such mental conditions could reveal the hidden causes of the domestica labes and thus help discover its remedies. The cynical charlatans of the "mystical" cults described by Lobeck made up the cures which prescribed the miserrimi homines to supplicate the angry dead in the midst of the funerary monuments, and the right piacula would remove the guilt of the fathers from the line once and for all. The devotiones of the mages, which people feared could curse them with the wrath of the restless dead, proceeded from the same superstitious logic.

$K \alpha \theta \alpha \varrho \mu o$, says Lobeck, have to do with such appeasements of the angry dead, supplications to the gods of the dead, and similar macabre nonsense. These are the types of superstitions which provided the material for the lustrationes of the religious charlatans which he describes in chapter 8 of the Orphica. For Lobeck, belief in pollution and purification is a late, post-Homeric development: a foreign contamination from the east superimposed on the simple and noble religion of the Olympians. ${ }^{24}$ The $x \alpha \theta \alpha \varrho \mu o i$ and $\tau \varepsilon \lambda \varepsilon \tau \alpha i$ mentioned by Plato in Phaedrus 244d refer to the sacra Phrygia ac Metragyrtarum negotia: that is, the obscene and cynical rites of purification of the eastern ecstatics whose vile cults came to be adopted by the inconstantia of the Greek religious spirit, and whose stories resemble nothing if not the Papistica Legenda. ${ }^{25}$ These are the cults, together with similar rites and beliefs coming from Egypt, which have provided the material for the cerimoniae Orphicae luctuosae et horridae of the Zagreus cycle developed by Onomacritus; they eventually came to represent and express the horrible $\pi \alpha \theta \dot{\eta} \mu \alpha \tau \alpha$ of Dionysos as $x \alpha \theta \alpha \varrho \mu$ oi and $\tau \varepsilon \lambda \varepsilon \tau \alpha i .{ }^{26}$ Instead of the 'erhabenen Naturdienst' of Lobeck's Romantic and Symbolist adversaries (nostri mythographi), superstitious beliefs such as ancestral fault are shown to be behind the rites and the religious experience of the Orphica. Such irrational ideas show ingenia inculta et indomita naturaliter ferocire rituque puerorum exsultando et vociferando sese explere. Ancestral fault is understood by Lobeck as a mistaken belief (opinio) in the transmission of guilt (culpa) through generations, and a corresponding practice of ritual funerary purifications (lustrationes). It is for him an immature error of popular superstitio.

\section{K.O. Müller: Eumeniden (1833)}

Four years after the publication of Lobeck's Aglaophamus, Karl Otfried Müller presented an altogether different view of ancestral fault in his Eumeniden (1833). ${ }^{27}$ In the Eumeniden, ancestral fault becomes an element of Müller's

\footnotetext{
24 LOBECK (1829), p. 300-301.

25 LOBECK (1829), p. 639.

26 LOBECK (1829), p. 698-699.

27 On Müller's Eumeniden, see MOsT (1998); GRAF (1998).
} 
Romantic projection of Greek religion as a canvas of aesthetic alterity. It is cast as the exotic object of a terrible and noble ancient spirituality. The most striking characteristic of Müller's scholarship on ancient religion is the empathy of the great descriptive frescoes in which he attempts to evoke the power and beauty of pagan religious feeling before nature. His Romantic valuation of antiquity as an aesthetic and moral source of inspiration is a characteristic which permeates his entire scholarly production. The Romantic aesthetic of this work is particularly evident in its valuation of absolute religious difference. Authentic Greek religion is a product of popular belief, it is close to the earth, and its simplicity is an expression of the unity of nature. It still sees correspondences where we make only divisions. Ancient faith becomes an essence of difference, a product of exotic fascination. It is a witness both to the original, authentic feeling of man before nature, and to the progressive constitution of distinctive national character. This religious national character is embodied in the different forms of cultus and cycles of myths carried by the different Greek tribes in their wanderings, and expressed by the differences of their poetry. Müller developed original theories on regional specificity in his work of cultural history, putting great emphasis on the distinctions between national groups and the thoroughness of historical change over time. He also looked for the more ancient strata of original, primordial religion. Müller's Romantic belief in the overwhelming imprint of nature on the mind of ancient man led him to search ancient religion for its universal elements. He attempted to identify the more authentic, ancient reactions to the power of nature, the early expressions of the noble and simple echoes of the world. In his work, the most ancient forms of Greek religion are presented as witnesses to a time when faith was a direct expression of awe before the universe. Poetry flows directly out of this religious feeling. To understand it, the modern interpreter needs to attune himself with the foreign logic of a different aesthetic and moral world.

In the Eumeniden, the belief in ancestral fault is shown not as the artificial concoction of cynical charlatans and superstitious error, but as an element of the most authentic ancient religion shared by all the Greeks. It is in fact a product of natural man's reaction to the awful power of primeval nature. The story which we find in Aeschylus contains the traces of the earliest strata of the belief in ancestral fault. It is an expression of the ancient religion of the Erinyes. For Müller, the Erinyes are both expressions of a natural human feeling, and primeval goddesses of nature. In talking of the very earliest strata of this religion, he says at the beginning of his section on the "religious point of view of the play:"

Jene Zeit, aus der wir die Volksreligionen und die auf ihrem Boden wachsende Poësie wie ein altes Erbe überkommen haben, und in die wir uns doch jetzt nur durch einen plötzlichen Sprung des Geistes versetzen können, unterscheidet sich von der unsern ganz besonders darin, dass sie alles geistige Leben, ja alles Leben überhaupt, als das beständige Wirken, nicht individueller Kräfte und Ursachen, 
sondern höherer dämonischer Gewalten ansieht, und den Menschen zum grossen Theil nur als den Focus betrachtet, in welchem diese Gewalten sich treffen und zur Erscheinung kommen. Jenes Gefühl schmerzlicher Kränkung und gerechten Grolles, welches ursprünglich દ̇@ıv́s hiess, ist nicht etwa blos ein Anlass und eine Aufforderung für gewisse Gottheiten, zu rächen und zu strafen; vielmehr ist es selbst schon dämonischer Art und von wunderbarer Gewalt, es erscheint gleichsam als ein Act aus dem Leben göttlicher Wesen, welche so ewig sind als die natürlichen Ordnungen, aus denen jenes Gefühl der Kränkung hervorgegangen ist. ${ }^{28}$

Subsisting in later times is a "perfect identity between the resentment of offended parents and the Goddess Erinnys," and both the "Erinnys atoned for" and the "Erinnys that brings the mischief" are one and the same. The differences which we posit between them are not functions of the material itself, but the misunderstandings of the great distances which exist between our modes of thinking and the wholly different ancient mind. Müller writes that:

Für uns hält gleichsam eine unübersteigliche Kluft auseinander, was ursprünglich Eins war, und der Unterschied der mythisch-poëtischen Weltanschauung und der sogennanten verständigen (welche doch, ebenso wie jene, nur einer bestimmten Periode des menschlichen Geistes angehört), ein Unterschied, welcher zuerst gar nicht vorhanden, und in der Zeit der epischen, so wie der ältern lyrischen Poësie, noch wenig ins Bewusstsein getreten war, fordert nun von uns sogar eine Bezeichnung durch die Schrift. ${ }^{29}$

The Erinyes were originally expressions of this prehistoric Gefübl which perceived the world in its unity of crime and atonement. As the myths started to "congeal" and crystallize over time in more fixed shapes, they eventually became individualized and came to be seen as independent beings, something which is already apparent in the poetry of Homer and Hesiod. The extended semantic field of the word égıvús gives us precious information for understanding the original religious feeling which underlies their individuation as divine beings. ${ }^{30}$ But, more importantly, the history of cult and myth can allow us to recover their true origin in primeval religion. Müller says that "the Erinnyes as great and venerable Goddesses is an idea founded on a more extensive system of views and thoughts, and manifested in legends and religious rites and ceremonies." "31 The Erinyes, in the extremely ancient common stock of beliefs which lies behind the real differences between the various national mythical cycles of the Greek tribes, were in fact "a particular form of the great Goddesses who rule the earth and the lower world and send up the blessings of the year, namely Demeter and Cora." 32 This is what explains their double nature, as

\footnotetext{
28 MÜLLER (1833), p. 166.

${ }^{29}$ MÜLleR (1833), p. 166.

30 Müller (1833), p. 165-168.

31 MÜLLER (1833), p. 168.

32 MÜller (1833), p. 168.
} 
benign and kindly beings of fertility, and as dread goddesses of vengeance. The unity of their nature in later poetry, such as the Eumenides, can only be understood in relation to their primeval role. Müller argues that this prehistoric figure of Demeter-Erinys has left its clearest traces in the old Arcadian cults of Thilphossa and Phigalia, and especially in the related ancient legends concerning the Cadmean Kings of Thebes. ${ }^{33}$ His research is an attempt "to recover those primeval conceptions from which a considerable portion of tragic Poetry originally emanated." ${ }_{34}$ Those primeval conceptions are idealized cosmic understandings of ancestral fault.

The whole of the Theban cycle, for Müller, is an expression of the twosided cosmic force of the Erinyes as Earth Goddess. ${ }^{35}$ The ancestral curse which afflicts the House of Cadmus over the generations is a symbolic projection of this religious reaction to the force of nature. The entire history of suffering of the Theban royal line is a representation of human confrontation with nature. At the beginning of the line, Cadmus had to slay the Dragon "begotten by Ares the God of War with Erinnys Tilphossa, i.e. the resentful, offended Demeter worshipped at Tilphossa; and from the sowing of this dragon's teeth springs the new Cadmean race of men." 36 For Müller, the mythical origin of the Cadmean race in the murder of the Dragon and the wrath of its genitors, including Demeter-Erinys, is the key to the ancestral curse

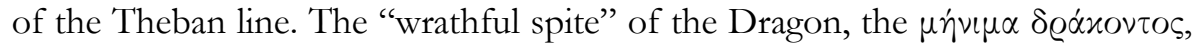
"continues to influence the whole course of the Theban Mythic History." ${ }^{37}$ It is what motivates the "continual vicissitudes of exalted fortune and deep misfortune" which are the characteristics of the legends surrounding every generation of the Cadmean kings, and even brought down by Pindar in the Second Olympian Ode to the calamities of the present age. This is what explains the cruel destiny of Cadmus already, forced by Ares to become a Dragon himself and to lead barbarian nations to ravage his own country. It is also what lies behind the stories of Laius and his descendants:

Der auf dem Geschlecht von Anfang an ruhende Fluch wirkt Vatermord, Blutschande, Brudermord, und indem mit der Ordnung der ethischen Welt auch die der physischen verkehrt wird, gehen Unfruchtbarkeit, Hungersnoth und Seuche daneben. Oedipus ist ganz und gar ein Geweihter der Erinnys, geboren, und durch seinen Fluch das Geschlecht zu verderben. ${ }^{38}$

The ancient wrath of the Dragon again resurfaces in the tales of the Seven against Thebes, especially clearly expressed in the figure of Adrastus, "the

\footnotetext{
33 MÜLLER (1833), p. 168.

34 MÜLLER (1833), p. 168.

35 MÜLLER (1833), p. 168-175.

36 MÜLLER (1833), p. 169.

${ }^{37}$ MÜLLer (1833), p. 169.

38 MÜLLER (1833), p. 169-170.
} 
Inevitable Avenger," who can be seen to represent the terrible wrath of Demeter-Erinys and Ares:

Er reitet den furchtbaren Gaul Areion, in dessen Namen der Vater des Drachen Ares wiederkehrt, den Thelpusäischen. Dieser Areion ist ganz und gar ein symbolisches Wesen aus dem Kreise des Cultus der Tilphossischen oder Thelpusäischen Demeter... Adrastos, der unentfliehbare Rächer, auf diesem schwarzmähnigen, schnellsten Rosse, an der Spitze des Argeierheers gegen das sündenvolle Theben heranziehend, in Namen und auf Geheiss der jetzt als Erinnys erscheinenden Schutzgöttin Thebens, ist ein Bild einer Phantasie von einer alterthümlichen Kühnheit und Grossartigkeit, wogegen Ilias und Odyssee als ungleich spätere Früchte eines viel milder und zahmer gewordnen Geistes erscheinen müssen. ${ }^{39}$

Theses tales of the classical period concerning the ancestral curses of the Erinyes are in fact emanation of a much more ancient age, the products of "authentic," primeval myths which go back to a time long before Homer. They are cosmic allegories. For Müller, they embody the awed reactions of prehistoric man before the terrible powers of nature:

Offenbar ist diese Drache, eine Hauptfigur der Thebanischen Mythologie, selbst schon ein Ausdruck des Grolles einer dunkeln Naturgewalt; Demeter ist schon Erinnys, ehe sie durch Menschen gereizt worden ist, und, wie in allen tiefern Theogonieen, wird das Böse als in einer höhern Welt und einem allgemeinern Naturleben schon gegeben vorausgesetzt, ehe es im Menschengeschlecht seine Früchte treibt. Es ist von Anfang an, so schien es jenen Menschen der Vorzeit, in den ewigen Naturmächten eine Seite des Furcht und Entsetzen erregenden; und wenn in der schönen und fruchtbaren Jahreszeit alles versöhnt und beruhigt scheint: so bricht in den Winterstürmen wiederkehrenden Schrecknissen der Natur der verhaltene Groll von Neuem hervor. Die anmuthreiche Gemahlin des Himmelsgottes, deren seegenschwangrer Schoofs das holde Kind Kora gebiert, ist zugleich eine Grause, unwillige Braut feindseliger Gottheiten. ${ }^{40}$

The continuity of the ancestral curse of the Dragon explains why from the delays of atonement "the sons were the first to suffer retribution for the sins of their fathers." 41 More importantly, it expresses the presence of Evil in the world, as an original stain carried by mankind before birth. ${ }^{42}$ The discussion of Müller shows how "Demeter, as a punient power, as Erinnys, is the predominant principle in the Theban legends." 43 The complementary double power of the natural force which is symbolized by the Great Mother Goddess, the divine force behind the logic of the legends, brings together life and death in a union of opposites. These are the two domains of action which the Erinyes will

\footnotetext{
${ }^{39}$ MÜLLER (1833), p. 173-174.

40 MÜLLER (1833), p. 169.

${ }^{41}$ MÜLLER (1833), p. 174: "Darum wurde erst an den Söhnen die Sünde der Väter gerächt.”

42 MÜLLER (1833), p. 168-169.

${ }^{43}$ MÜLLER (1833), p. 174.
} 
inherit after their individuation and separation from the primeval mother figures. Even in historical times, they will continue to rule over the complementary cycles of life and death:

Nach allem Diesem, glaub' ich, kann kein Zweifel sein, dass - obzwar schon an sich die Erinnys, jenes Gefühl der Kränkung ein göttliches ist - doch die Erinnyen erst dadurch einen ansehnlichen und ausgebreiteten Cultus, und überhaupt mehr Realität und Persönlichkeit erlangt haben, dass man die beiden grossen Erd- und Unterweltsgottheiten, durch welche den Menschen Leben und Gedeihen, aber auch Untergang und Tod kömmt, als die gekränkten und grollenden fasste, wo irgend der Menschen Thun jene heiligen und ewigen Urgesetzte verletzt. ${ }^{44}$

These tales of the Erinyes are older than Homer, and the adaptations of the tragedians reproduce the religious sentiments of much earlier times. Through the content of the myths, Müller is even able to trace the development of these tales in stages in prehistoric times, and map the contours of their diffusion through the movements of the various Greek tribes. ${ }^{45}$ But what is important in the case of the Theban legends is that they embody a fund of myths common to all Greeks, which goes back to prehistoric times. The ambivalent power of the Erinyes as goddesses of fertility and death is a principle of the common Greek national legend. The continuation of its vengeance over generations in traditional tales is a symbolic expression of this primeval understanding of nature as the common source of "death and ruin, as well as life and welfare." Ancestral fault is a cosmic principle.

Müller presents the concept of ancestral fault as a foundation of the Theban legends, but he also finds it at work in other cycles, most notably the myths of the Atreidae, of course. The principle of ancestral fault which animates the legends of the House of Atreus has the same cosmic logic as the one which Müller presents for the line of Cadmus. Oedipus and Orestes are shown to be similar, almost equivalent mythical figures expressing the powerless reaction of man to the awful power of nature, and the transmutation of suffering into grace. Both are linked to the transformation of the Erinyes into Eumenides, and both to the value of unjust suffering in the acceptation of the world and the overcoming of Evil. In talking about the myth of Oedipus at Colonus, Müller writes that:

Es ist ein Gedanke, der, wenn, er auch meist sehr zurücktritt, doch auch dem Alterthume nicht fremd war; das grosses Leid die menschliche Natur läutere und verkläre; die Zerstörung des Selbstischen, die Alterthum als eine Vergöttlichung gefühlt; und jene Geweihten der Erinnys sind darum nach ihrem Tode erhabne Dämonen. Dieselben Ideen knüpften sich auch an Orestes... ${ }^{46}$

\footnotetext{
${ }^{44}$ MÜLLER (1833), p. 176.

${ }^{45}$ MÜLLER (1833), p. 176-177.

46 MÜLLER (1833), p. 172.
} 
Later, in discussing the case of Orestes, he says:

Eben so knüpfte sich die Verwandlung der Erinnyen in Eumeniden in der Volksage die wir oben bei den Mykenäern selbts nachgewiesen haben, an die Befreiung des Orestes von der Blutrache an; die Gottheit, die den Orestes verfolgt hatte, wird nun für ihn ein Seegenswesen, er selbst, so zu sagen, ein Heiliger, wie Oedipus. ${ }^{47}$

The tales of both heroes are functions of the same logic, the reaction of man to Evil and suffering, and the deep association of this suffering with the gift of life and the fertility of nature. The rewriting of this ancient "ethicoreligious idea" in the trilogy of Aeschylus as a political justification of the Areopagus and of the justice of Athenian institutions is entirely in line with the older strata of the myth, where the "curse, rooted in the human race and generating one misdeed out of another, is averted by the superior control of the saving God, in a case where only the family-destiny and no guilt of his own weighs upon the curse-possessed person." 48 In the Eumeniden, the stain of the original fault which courses through generations is an expression of this sublime portrayal of man's place in the cosmos, adapted to the realities of Athenian life in the classical period. In Müller's understanding of the cycles of Thebes and Argos, ancestral fault is a fundamental key to the interpretation of tragedy as poetry which flows from deep religious feeling. It is a central element of the common Greek national faith.

The portrait of ancestral fault produced by Lobeck in the Aglaophamus and Müller in the Eumeniden are exact contemporaries. These two influential representations of Greek ancestral fault were written at the two opposite ends of the new professional, German philology of the period; one from the analytic perspective of the Hermann school, the other from the more synthetic approach of Sach-Philologie. Although so clearly distinct from each other, the discussions of Lobeck and Müller both remained grounded in the obligatory Judeo-Christian frame of reference of the period: the Hebrew notion of corporate responsibility ("the sins of the fathers"), and original sin. These categories from the Judeo-Christian tradition lie behind both authors' framing of the Greek material. The Begrifflichkeit of the avita culpa and the Erbsünde of the $\mu \eta \dot{\nu} \iota \mu \alpha \delta \varrho \alpha \dot{x} о \nu \tau o \varsigma$, described by Lobeck and Müller as distinct objects of study, is entirely conceived through the apparently equivalent notions of the Christian tradition. The meanings attributed to these Christian notions determine the meaning of the Greek material in this operation of religious translation.

For the Rationalist Protestant Lobeck, Greek ancestral fault is a product of inauthentic, artificial religious manipulation. It has its roots in the deepest impulses of the irrational, in madness and hysteria. It is based on the archaic

\footnotetext{
${ }^{47}$ MÜLLER (1833), p. 177.

48 MÜLLER (1833), p. 197.
} 
law of the family, which doesn't recognize the individual and the state yet. It is tied to the rise of belief in pollution, the treason of the priests and their imposition of purification and empty ritual over the fears of men. It is a secondary elaboration of human obscurantism. For the Romantic Pietist Müller, on the other hand, the wrath of the dragon is an echo of true, original religious feeling, still resonating with the direct experience of nature before individuation. It is a primeval expression of participation in the universe, out of which the idea of the individual will grow. It embodies a "stern reciprocal justice, recalling the Old Testament but not the New," in the words of Hugh Lloyd-Jones, who directly drew from Müller's vision in his own understanding of "the doctrine of inherited guilt." 49 The opposite and complementary portraits of the Greek material presented by Lobeck and Müller set the stage for all succeeding work on the topic. The more elaborate discussions of Gustave Glotz (1904) and Eric Robertson Dodds (1951) on the question, for instance, on which most relevant contributions of the 20th century are directly dependant, reproduce many of the problems and questions found in Lobeck and Müller, notably the definition of ancestral fault in terms of origin, purification, and ritual. Cultivating the deep tradition of scholarship on Greek religion is a key to understanding how the questions and problems of the field emerged, of course, but also to recover the explicit values still active behind most implicit assumptions of research. In the case of ancestral fault, it is a necessary step for any serious attempt at redefining the material.

Renaud GAGNÉ

McGill University

E-mail:renaud.gagne@mcgill.ca

${ }^{49}$ LLOYd-Jones (1983), p. 107. 


\section{Bibliography}

A. Bernabé, "La toile de Pénélope: a-t-il existé un mythe orphique sur Dionysos et les Titans?," RHR 219 (2002), p. 401-433.

A. BernabÉ, "Autour du mythe orphique sur Dionysos et les Titans. Quelques notes critiques," in D. Accorinti, P. Chuvin (éds), Des Géants à Dionysos. Mélanges offerts à F. Vian, Alessandria, 2003, p. 25-39.

J.H. BLOK, “'Romantische Poesie, Naturphilosophie, Konstruktion der Geschichte': Karl Otfried Müller's Understanding of History and Myth," in W.M. CALDER III, R. SCHLESIER (éds), Karl Otfried Müller und die antike Kultur, Hildesheim, 1998, p. 55-97.

W. BurkerT, "Griechische Mythologie une die Geistgeschichte der Moderne," in O. REVERDiN, B. GRANGE (éds), Les études classiques aux XIXe et XXe siècles: leur place dans l'bistoire des idées, Genève, 1980, p. 159-207.

W. BurkerT, Greek Religion, trans. J. Raffan, Cambridge, Mass., 1985 [1977].

W.M. CALDER III, R. SCHLESIER (éds), Zwischen Rationalismus und Romantik: Karl Otfried Müller und die antike Kultur, Hildesheim, 1998.

E.R. DoDDs, The Greeks and the irrational, Berkeley, 1951.

A.M. DuBARLE, Le péché originel : Écriture et tradition, Paris, 1999.

R. EDMONDS III, "Tearing apart the Zagreus myth: A few disparaging remarks on Orphism and original sin," CA 18 (1999), p. 35-73.

T. GANTZ, "Inherited guilt in Aeschylus," CJ 78 (1982), p. 1-23.

F. GraF, "Karl Otfried Müller: Eleusinien," in W.M. CALDER III, R. Schlesier (éds), Karl Otfried Müller und die antike Kultur, Hildesheim, 1998, p. 217-238.

E. Gössmann, Johann-Heinrich Feustking: Gynaeceum haeretico-fanaticum, oder, Historie und Beschreibung der falschen Prophetinnen, Quäckerinnen, Schwämerinnen und andern sectirischen und begeisterten WeibesPersonen, Munich, 1998.

J.T. KAKRIDIS, “A@ $\alpha$ i,” Athens, 1929.

B. LeHMANN, "Sach- und Wortphilologie in der deutschen klassischen Altertumswissenschaft des 19. Jhs," WZBerlin 36 (1987), p. 15-19.

I.M. Linforth, "Telestic madness in Plato, Phaedrus 244de," University of California Publications in classical Philology 13 (1946), p. 163-172.

H. LLOYD-JONES, "Zeus in Aeschylus," JHS 76 (1956), p. 55-67.

H. Lloyd-Jones, “The guilt of Agamemnon,” CQ 12 (1962), p. 187-199.

H. LLOYD-Jones, The justice of Zeus, Berkeley, $1983^{2}$.

H. Lloyd-Jones, "Curses and divine anger in early Greek epic: The Pisander scholion," CQ 52 (2002), p. 1-14.

C.A. LOBECK, Aglaophamus, sive de theologiae mysticae Graecorum censis libri tres, Königsberg, 1829.

J. LOMEIER, De veterum gentilium lustrationibus syntagma, Utrecht, 1681 (2nd edition 1700: Epimenides).

M. Lossau, "Christian August Lobeck (1781-1860)," Die Albertus Universität zu Königsberg, 1995, p. 283-293.

M. Lossau, "Von Christian August Lobeck bis Ludwig Friedländer: Das grosse Jahrhundert der Königsberger Philologie," AKG 78 (1996), p. 207-224.

G. Minors, Les origines du Mal. Une histoire du péché originel, Paris, 2002.

A. Momigliano, "Friedrich Creuzer and Greek historiography," in G.W. Bowersock, T.J. CORNELL (eds), Momigliano: studies in modern scholarship, Berkeley, 1994 [1946], p. 1-14.

A. Momigliano, "K.O. Müller's Prolegomena zu einer wissenschaftlichen Mythologie and the meaning of 'Myth'," ASNP 13 (1983), p. 673-689. 
G.W. Most, “Karl Otfried Müller's Edition of Aeschylus' Eumenides,” in W.M. CALDER III, R. SCHLESIER (éds), Karl Otfried Müller und die antike Kultur, Hildesheim, 1998, p. 349-373.

L. Moulinier, Le pur et l'impur dans la pensée des Grecs d'Homère à Aristote, Paris, 1952.

K.O. MüLLER, Aischylos Eumeniden, Göttingen, 1833.

R. PARKer, Miasma. Pollution and purification in early Greek religion, Oxford, 1983.

R. SCHLESIER, “'Dieser mystische Gott': Dionysus im Spiegel von Karl Otfried Müllers Religionstheorie," in W.M. CALDER III, R. SCHLESIER (éds), Karl Otfried Müller und die antike Kultur, Hildesheim, 1998, p. 399-422.

N.J. Sewell-RutTer, Guilt by Descent: Moral Inheritance and Decision-Making in Greek Tragedy, Oxford, 2007.

R. VALLOIS, “Arai,” BCH 38 (1914), p. 250-271.

M.L. WeSt, "Ancestral curses," in Sophocles revisited. Essays presented to Sir Hugh Lloyd-Jones, ed. J. Griffin, Oxford, 1999, p. 31-45.

U. von Wilamowitz-MÖLLENDorfF, Der Glaube der Hellenen, 2 vol., Berlin, 1931-1932. 